\title{
Szczęście człowieka jako problem filozoficzno-psychologiczny na przestrzeni dziejów
}

\section{Happiness as a Philosophical and Psychological Problems}

Termin „szczęście” w psychologii i socjologii nie doczekał się jednej zwartej definicji. Zakres znaczeniowy terminu związany jest z różnicami kulturowymi i językowymi ${ }^{1}$. Szczęście może być rozumiane jako „pełne i trwałe zadowolenie z całości życia”, ,jako trwały stan najwyższego zadowolenia” ${ }^{3}$ czy „zadowolenie z życia albo częstość i intensywność przyjemnych emocji doświadczanych przez człowieka” ${ }^{4}$ Janusz Czapiński, autor „cebulowej teorii szczęścia”, zakłada, że „szczęście, rozumiane jako pozytywna, afirmująca postawa wobec życia, jest pierwotnym, naturalnym i powszechnym, niezależnym zasadniczo od okoliczności życia i indywidual-

1 J. Czapiński, Psychologia szczęscia. Przeglad badań i zarys teorii cebulowej, Warszawa 1992.

2 W. Tatarkiewicz, Historia filozofii. t. 1: Filozofia starożytna i średniowieczna, Warszawa 1997, s. 31.

3 R. Veenhoven, Conditions of Happiness, Dordrecht 1984, za: J. Czapiński, Psychologia szczęścia, dz. cyt., s. 11.

4 M. Argyle, The Psychology of Happiness, London 1987, za: J. Czapiński, Psychologia szczęścia, dz. cyt., s. 11. 
nej biografii, stanem psychicznym, zakorzenionym we wrodzonej woli życia"s , zaś poczucie nieszczęścia uzależnione jest od doświadczeń i indywidualnych zmiennych. Zatem szczęście jest pierwotnym, ogólnym i naturalnie przypisanym człowiekowi stanem, co jednocześnie nie wyklucza zróżnicowania w sposobach jego przeżywania ${ }^{6}$.

Analizując historię myśli filozoficznej na temat szczęśliwości życia, uwagę zwraca różnorodność i przenikanie się wątków, co daje szeroki wachlarz możliwości doboru kryteriów. Poniżej przedstawiono wybrane zagadnienia na temat szczęścia wyselekcjonowane na podstawie kilku tematów porządkujących.

\section{Szczęściem jest poznanie prawdy i cnota oraz praktykowanie cnót}

Pierwszym myślicielem, który przedstawił koncepcję życia zgodnego z dobrem był S o kr a te s (469-399 p.n.e.). Filozofia Sokratesa dała początek humanistycznemu nurtowi, który w centrum rozważań stawiał człowieka. „Sokrates formułuje następującą myśl: kiedy człowiek działa, czyni to zwykle dlatego, że zamierza uzyskać coś, co uważa za dobre"7. Głównym zadaniem człowieka jest poznanie samego siebie, odkrycie poczucia prawdy, ale i słabości - niewiedzy, która prowadzi do zła. Można rzec, że Sokrates za szczęście uważał dochodzenie do prawdy. Filozof promował postawę indywidualistyczną w przeciwieństwie do ateńskiego ideału - życia publicznego. Ponieważ dusza rozpoznaje co dobre, dostarczając wiedzy etycznej, zatem istotne jest dbanie o duszę ${ }^{8}$ Szczęście wynika z cnoty. Człowiek szczęśliwy, to ten, kto posiada największe dobro, a tym dobrem jest cnota9. Dla Sokratesa cnota jest wiedzą, wadą jest niewiedza. Szczęście jest tym samym, co cnota $^{10}$. „Ludzie dążą do szczęścia i pożytku. Prawdziwe szczęście i pożytek daje tylko dobro. Prawdziwym dobrem jest cnota. Cnota jest jedna, bo każda cnota jest wiedzą.

\footnotetext{
J. Czapiński, Psychologia szczęścia, dz. cyt., s. 143.

6 Tamże.

7 J. Hersch, Wielcy myśliciele Zachodu. Dzieje flozoficznego zdziwienia, przeł.

K. Wakar, Warszawa 2001, s. 21.

$8 \quad$ K. Kaszyński, Wybrane elementy flozofii cztowieka, Zielona Góra 2002, s. 29.

9 W. Tatarkiewicz, Historia filozofii, t. 1., dz. cyt., s. 74.

10 J. Bocheński, Zarys historii filozofii, Kraków 1993, s. 49.
} 
Zdobywając wiedzę, osiągamy dobro, a z nim pożytek i szczęście"11. Zatem człowiek szczęśliwy, to człowiek poszukujący wiedzy. Intelektualizm etyczny Sokratesa oparty jest na tezie, że wiedza pozwala odkryć dobro - cnotę, co w konsekwencji prowadzi do szczęścia. Teza ta ma skrajne założenia, które postulują uwolnienie od dóbr doczesnych i potrzeb zmysłowych, bowiem do szczęścia wystarcza rozum ${ }^{12}$.

Poglądy Sokratesa zostały przejęte przez szkołę cynicką, której założycielem był A n t y s te n e s (ok. 444/436-ok. 365 p.n.e.), uczeń Sokratesa. Według myśliciela do szczęścia potrzebna jest tylko cnota, wszystko inne nie ma znaczenia. Szczęście ma charakter ponadmaterialny. Tezy na temat szczęścia prezentowane przez szkołę cyników były związane z warunkami życia, w jakich żyli ich autorzy. Ponieważ nie należeli do warstwy majętnej, stan szczęśliwości wiązali z cnotą i obojętnością wobec dóbr materialnych. Założenia te dały początek szkole stoickiej ${ }^{13}$.

Teza o cnocie jako szczęściu obecna jest w filozofii Pla tona (427-347 p.n.e.). Początkowo Platon przyjmował stanowisko Sokratesa o jedności cnoty i wiedzy, z czasem jednak doszedł do wniosku, że cnota nie zależy tylko od rozumu. Rozróżniając trzy części duszy przyjął, że każda jej część posiada cnotę. Mądrość należy do rozumnej części duszy, męstwo do jej części impulsywnej duszy, zaś panowanie nad sobą do części pożądliwej. Czwarta cnota - sprawiedliwość, łącząca trzy części duszy, utrzymuje ład i harmonię. Życie pełne i radosne zależy od rozumu, cnoty, ale również i radości ${ }^{14}$. „Z piękna wiedzy i harmonijnego ukształtowania życia płynie czysta radość" ${ }^{15}$. Ponieważ cnota związana jest z duszą, wszystko co zmysłowe należy odrzucić i poszukiwać wiedzy filozoficznej. Posiadając wiedzę, sięgamy do świata idei, by osiągnąć szczęście.

W filozofii Arys to tele s a (384-322 p.n.e.) szczęście rozumiane jest jako cel ostateczny każdej działalności. „[... ] szczęście jest dobrem najwyższym i samo-celowym, a polega na praktykowaniu ćwiczeniem nabytych sprawności moralnych, czyli cnót; sprawności tych

11 W. Tatarkiewicz, Historia filozofii, t. 1, dz. cyt., s. 75.

12 K. Kaszyński, Wybrane elementy flozofii cztowieka, dz. cyt., s. 29.

13 W. Tatarkiewicz, Historia filozofii, t. 1, dz. cyt., s. 79.

14 Tamże, s. 98.

15 Tamże. 
uczymy się, szukając środka miedzy skrajnościami”"16. „Poszczególne istnienia odczuwają przyjemność, realizując jako akt to, do czego są zdolne"17. Dyspozycją sprawnego funkcjonowania jest cnota. Sprawność zaś determinuje zdrowie, zamożność, dobre stosunki z rodziną. Istotą szczęścia jest czynienie tego, co dobre i piękne, do których to czynów Arystoteles zalicza kontemplację naukową ${ }^{18}$. Rozum jest osnową życia doskonałego, prowadzi on do szczęścia ${ }^{19}$. Arystoteles, podkreślając wartość wiedzy i istotę rozumu, nie proponuje wyrzeczenia się dóbr. „Okazuje się jednak, iż szczęście [...] nie może się obejść bez dóbr zewnętrznych; wszak niemożliwą jest rzeczą dokonywać czynów moralnie pięknych, będąc pozbawionym odpowiednich środków"20. W działaniu filozof wyznaje zasadę złotego środka. „[...] dzielność etyczna polega na zachowaniu właściwego środka, i to środka pomiędzy dwiema wadami, z których jedna pochodzi z nadmiaru, druga zaś z niedostatku, i że posiada te właściwości, ponieważ zmierza, zarówno w doznawaniu namiętności jak i postępowaniu, do właściwego środka jako do swego celu"21.

W prezentowanych poglądach szczęściem jest dążenie do wiedzy, odkrywanie cnoty i jej pielęgnowanie. Zaspokajanie potrzeb zmysłowych nie wystarcza by być szczęśliwym, a nawet, jak zakłada Platon, należy owe potrzeby odrzucić i skupić się na działaniu duszy.

\section{Szczęście jako hedonistyczne realizowanie przyjemności oraz pogodny dystans wobec świata i własnych potrzeb}

Skrajnie inny pogląd na szczęście reprezentował drugi uczeń Sokratesa Arystyp z Cyreny (ok. 435-366 p.n.e.), założyciel szkoły cyrenaickiej. W przeciwieństwie do Sokratesa, który uważał że dobro daje przyjemność, Arystyp twierdził, że to właśnie przyjemkowski, Problemy etyki. Wybór tekstów, Agencja Marketingowa „Branta”, Bydgoszcz 1993, s. 29.

21 Tamże, s. 30. 
ność jest jedynym dobrem. Wyznając hedonistyczny model szczęścia, uważał, że człowiek dąży do przyjemności i unika przykrości. Ponieważ przyjemności trwają krótko, człowiek powinien zabiegać o przyjemności częściowe i je gromadzić. Przyjemności mają charakter cielesny, nie różnią się jakością ale intensywnością ${ }^{22}$.

Podobne założenia na temat szczęścia przyjął Epikur (341270 p.n.e), stwierdzając, że „[...] bezustannie należy zabiegać o to, co może przysporzyć nam szczęścia; kto bowiem posiadł szczęście ma wszystko, co w ogóle mieć można, kogo zaś szczęście ominęło robi wszystko, by je zdobyć”23. Jednak dla filozofa prawdziwe szczęście - ,ataraksja” to osiągnięcie wewnętrznego spokoju. Niezależność wobec świata i umiarkowane czerpanie z dóbr prowadzą do pokoju duszy $^{24}$. Szczęście zapewnia radość życia, zaspokojenie zewnętrznych potrzeb, nad którymi czuwa rozum.

Nie pijatyki i hulanki, nie obcowanie z pięknymi chłopcami i kobietami; nie ryby i inne smakołyki, jakich dostarcza zbytkowy stół, czynią życie przyjemnym, ale trzeźwy rozum dociekający przyczyn wszelkiego wyboru i unikania, odrzucający czcze domysły, owo źródło największych utrapień duszy. [...] mądrość jest początkiem wszelkiego dobra i dobrem najwyższym, a wskutek tego jest cenniejsza nawet od filozofii, jako źródło wszystkich innych cnót. Ona nas uczy, że nie można żyć przyjemnie jeśli się nie żyje mądrze, pięknie i sprawiedliwie, i na odwrót, że nie można żyć mądrze, pięknie i sprawiedliwie jeśli się nie żyje przyjemnie ${ }^{25}$.

Do szczęścia wystarcza brak cierpienia. „Przyjemność [...] charakteryzuje nieobecność cierpień fizycznych i brak niepokojów duszy"26. Zaspokojenie zewnętrznych potrzeb daje radość, jednak najwięcej przyjemności posiada ten, kto ma mniej potrzeb. Potrzeby mają charakter fizyczny lub duchowy, a między nimi nie istnieje różnica jakościowa. Jednak według Epikura należy zabiegać o przyjem-

25

26

W. Tatarkiewicz, Historia filozofi, t. 1, dz. cyt., s. 81.

Epikur, List do Menoikeusa, w: Diogenes Laertios. Żywoty i poglady stynnych filozofów, przeł. I. Krońska, K. Leśniak, W. Olszewski, Warszawa 1988, s. 643-650, za: S. Sarnowski, E. Frykowski, Problemy etyki, dz. cyt., s. 40.

${ }^{4}$ J. Hersch, Wielcy myśliciele Zachodu, dz. cyt., s. 52.

Epikur, List do Menoikeusa, dz. cyt., s. 40.

Tamże. 
ności duchowe, przyjaźń i szlachetne życie ${ }^{27}$. Na drodze do szczęścia stoi strach przed bogami i śmiercią, jednakże bogowie nie ingerują w nasz świat, bowiem jest on kierowany fizycznym mechanizmem, a „dopóki żyjemy, nie ma śmierci; kiedy jest śmierć, nas już nie ma”"28. Najwyższym szczęściem jest zatem życie w pogodnej niezależności od lęku, życie spokojne i przyjemne.

Poglądy Epikura niewiele różnią się od filozofii wyznawanej przez s toików z głównymi przedstawicielami szkoły: Zenonem z Kition (336-269 p.n.e.), Chryzypem (280-206 p.n.e.), Seneką (336), Epiktetem (50-130), Markiem Aureliuszem (121-180). Według wyznawców stoicyzmu szczęściem człowieka jest życie zgodne z rozumem uniwersalnym i boskim prawem. Ważne jest zaangażowanie w życie społeczne i polityczne jednoczące człowieka ze światem. Zachowanie wewnętrznej pogody ducha i dystansu wobec świata pozwala żyć szczęśliwie ${ }^{29}$. Jedynym prawdziwym dobrem jest cnota, która wystarcza do doskonałości. Podobnie jak Sokrates, twierdzili, że cnota to wiedza o dobru. „Cieszy się człowiek gdy czyni to, co jest właściwe człowiekowi. Właściwe zaś jest: być życzliwym dla tych, którzy są mu pokrewni, gardzić podnietami zmysłowymi, odgraniczać ściśle wyobrażenia wiarygodne, wszechnaturę i jej dzieła”30. Istotą stoickiej myśli jest surowość i rygoryzm, które nakazywały opanowanie afektów i obojętność wobec dóbr życiowych ${ }^{31}$. „Mędrzec zadowala się sobą, nie po to aby żyć, lecz po to, by żyć szczęśliwie. Do życia potrzebuje wielu rzeczy, do życia szczęśliwego zaś konieczny jest dlań tylko zdrowy, wzniosły, pogardzający losem duch”32.

\section{Bóg źródłem szczęścia}

Okres średniowiecza, kiedy myśl filozoficzna została podporządkowana teologii, przyniósł inne rozumienie szczęścia. Najwyższym

27 W. Tatarkiewicz, Historia filozofii, t. 1, dz. cyt., s. 140.

28 J. Hersch, Wielcy myśliciele Zachodu, dz. cyt., s. 52.

29 Tamże, s. 57.

30 Marek Aureliusz, Rozmyślania, przeł. M. Reiter, Warszawa 1958, za: S. Sarnowski, E. Frykowski, Problemy etyki, dz. cyt., s. 33.

31 W. Tatarkiewicz, Historia filozofii, t. 1, dz. cyt., s. 134.

32 Seneka, Listy moralne do Lucyliusza, przeł. W. Kornatowski, Warszawa 1961, za: S. Sarnowski, E. Frykowski, Problemy etyki, dz. cyt., s. 35. 
celem człowieka według św. Augu styna (354-430) jest dążenie do Boga, jest to droga do szczęścia człowieka. Centrum myśli filozoficznej św. Augustyna stanowi Bóg - najwyższe dobro. Szczęście ludzkie możliwe jest tylko i wyłącznie w Bogu i poprzez łaskę Boga. Istotą zjednoczenia z Bogiem jest pełnienie dobra. Według Augustyna „[...] szczęśliwy ten, kto posiada Boga. [....] Boga posiada każdy, kto dobrze żyje, kto spełnia jego wolę i nie ma ducha nieczystego"33. Nie samo poznanie, ale posiadanie poznania daje szczęście. „Pragnę znać Boga i duszę. I nic więcej? Nic więcej”34. Zrywając z intelektualizmem, Augustyn opowiada się za woluntaryzmem, twierdząc, że poznanie dokonuje się nie tyle rozumowo, co za sprawą woli serca - miłości. „Tylko z miłości płyną dobre czyny, zwłaszcza z miłości do dobra najwyższego, do Boga; szczęście można osiągnąć jedynie przez miłość, bo przez miłość a nie wysiłek myśli można zbliżyć się do Boga" 35 .

Z kolei św. Tomasz z Akwinu (1225-1274), podobnie jak Augustyn, szczęście lokował w Bogu, jednak zaznaczał, że do osiągnięcia szczęścia niezbędny jest akt intelektualny i pełnienie obowiązków na ziemi. Opowiadał się za racjonalizmem w poznaniu Boga, zaś jako pierwszy atrybut Boga uznawał rozum ${ }^{36}$.

Pełnieniu dobrych czynów sprzyja cnota warunkująca sprawność postępowania. Cnota ta nie zawsze leży, jak mniemał Arystoteles, miedzy dwiema skrajnościami, tj. między niedomiarem i nadmiarem. Wśród cnót Tomasz wyróżnił trzy cnoty teologiczne: wiarę, nadzieję i miłość oraz cztery platońskie cnoty główne. To one to warunkują dobre czyny ${ }^{37}$. Człowiek żyjący zgodnie z prawem Bożym może osiągnąć szczęście, bo „[...] prawo od Boga nadane kieruje więc człowieka przede wszystkim do jego celu. Celem zaś stworzenia rozumnego jest złączyć się z Bogiem; na tym polega jego szczęśliwość”38.

33 Za: S. Sarnowski., E. Frykowski, Problemy etyki, dz. cyt., s. 46,48.

34 W. Tatarkiewicz, Historia filozofii, t. 1, dz. cyt., s. 195.

35 Tamże, s. 199.

36 J. Bocheński, Zarys historii fllozofii, dz. cyt., s. 137.

37 Tamże.

38 Tomasz z Akwinu. Summa teologiczna (Contra Gentiles), cz. 1, t. 3, przeł. Z. Włodkowa, Nakładem „Wiadomości Katolickich”, Kraków 1933, za: S. Sarnowski, E. Frykowski, Problemy etyki, dz. cyt., s. 54. 
Podobne założenia $\mathrm{w}$ dobie odrodzenia przyjął $\mathrm{B}$ aruch Spinoza (1632-1677). Zwrócił uwagę na rolę intelektu w poznaniu prawdziwej rzeczywistości, czyli Boga. Poznanie Boga wzbudza miłość do niego i prowadzi do mistycznego zjednoczenia się z nim. Jest to możliwe, bo Bóg uobecnia się w innych ludziach i w świecie ${ }^{39}$. Dominującym zagadnieniem etyki Spinozy jest wolność i konieczność. „Największe szczęście polega na tym, by sprawić, że własna wolność okaże się identyczna z koniecznością bożąa" ${ }^{\prime 0}$. Namiętności duszy ograniczają poznanie, toteż należy je opanować siłą woli. Wolność związana jest $\mathrm{z}$ radością, jest ona podporządkowana boskiej konieczności. Zatem człowiek szczęśliwy, to osoba wolna, choć podporządkowana boskiej konieczności.

\section{Szczęście jako dbanie o własne dobro oraz utylitaryzm}

Poglądy naturalistyczne i materialistyczne obecne są w filozofii Thomasa Hobbes a (1588-1679). Jedyne dobro, jakie człowiek może realizować, to indywidualizm i egoizm. Filozof zanegował pogląd Arystotelesa na społeczną naturę człowieka. „Ludzie nie znajdują przyjemności w życiu gromadnym (przeciwnie, raczej znajdują wiele przykrości), gdzie nie ma mocy, która by była zdolna trzymać w strachu ich wszystkich" ${ }^{\prime 1}$. Szczęściem jest dbanie o własne dobro i zaspokajanie indywidualnych potrzeb ${ }^{42}$.

Przeciwny pogląd reprezentowal Gottfried Wilhelm Leib niz (1646-1716), wskazując, że człowiek jest istotą społeczną, dla którego dobro ogólu stanowi istotny czynnik. Podobnie jak Arystoteles, Leibniz uważał, że szczęście jest celem człowieka, do którego dochodzi się poprzez działanie. Istotna jest mądrość i harmonia, zaś główną cnotą sprawiedliwość ${ }^{43}$.

Wieki XVIII i XIX obfitują w teorie utylitarystyczne. Zgodnie z tymi założeniami człowiek powinien dążyć do przyjemności, kierować się rozumem, ale tak, by budować szczęście ogólu. „Moralność

\footnotetext{
39 J. Bocheński, Zarys historii fllozofii, dz. cyt.

40 J. Hersch, Wielcy myśliciele Zachodu, dz. cyt., s. 100.

41 S. Sarnowski, E. Frykowski, Problemy etyki, dz. cyt., s. 66.

42 W. Tatarkiewicz, Historia filozofii, t. 2, dz. cyt, s. 68.

43 J. Bocheński, Zarys historii filozofii, dz. cyt., s. 171.
} 
utylitarystów uznaje w człowieku zdolność poświęcenia swojego własnego, największego dobra dla dobra innych. Zaprzecza tylko temu, by poświęcenie to było samo przez się dobrem i uważa je za marnotrawstwo, jeżeli nie powiększa ogólnej sumy szczęścia albo nie zmierza do jej powiększenia"44.

\section{Znaczenie nauki i wiedzy empirycznej oraz uczuć dla szczęścia człowieka}

W epoce odrodzenia odrzucono średniowieczną myśl jakoby wiedza była podporządkowana wierze. Nastąpił powrót do źródeł antycznych, oddano zasługi ludzkiemu rozumowi i skupiono się na eksperymentach i doświadczeniu. Okres ten obfitował wielością i różnorodnością poglądów na temat człowieka.

Człowiek jest twórcą własnego losu i częścią przyrody. Miarą człowieka renesansu są dzieła użyteczne społecznie ${ }^{45}$. Słynne powiedzenie Kartezjus za (1596-1650) „myślę, więc jestem” wskazuje na wage jaką przypisano rozumowi ludzkiemu. W kwestii szczęścia Kartezjusz doradza pracę nad umysłem i sądem, by zrozumieć porządek stworzony przez Opatrznośćc ${ }^{46}$.

Okres oświecenia z głównymi jego przedstawicielami Johnem Locke'em (1632-1704), George'em Berkeleyem (1684-1753) i Davidem Hume’em (1711-1776) przyniósł w Anglii rozwój myśli empirycznej. Wszelka wiedza zdaniem L o cke' a pochodzi z doświadczenia, idee wrodzone nie istnieją, gdyż umysł jest niezapisaną tablicą. Filozof wyznawał ideę wolności i indywidualnego rozwoju. Można by rzec, że szczęście znaczy tyle, co realizowanie swych pragnien, byle w sposób rozumny. „Rozum powinien kontrolować wiarę" ${ }^{47}$.

Podkreślane w dobie oświecenia wartości rozwoju nauki, empiryzmu, optymizmu zostały podważone w filozofii J e a n a - J a c qu e s a Rous se au (1712-1778). Dla filozofa to cywilizacja jest źródłem zła i cierpienia. Istotą rozważań Rousseau na naturę człowieka stano-

44 J.S. Mill, Utylitaryzm. O wolności, przeł. A. Kurlandzka, Warszawa 1959, za:

S. Sarnowski, E. Frykowski, Problemy etyki, dz. cyt., s. 95.

45 K. Kaszyński, Wybrane elementy filozofii cztowieka, dz. cyt., s. 60.

46 J. Hersch, Wielcy myśliciele Zachodu, dz. cyt., s. 96.

47 J. Bocheński, Zarys historii filozofii, dz. cyt., s. 174. 
wi myśl o istnieniu konfliktu pomiędzy istnieniem wolnym i narzuconym, aspołecznym i społecznym. Celem człowieka jest kierowanie się uczuciem i sercem ${ }^{48}$.

Szczęściem jest stan pierwotny, powrót do natury. Wizja człowieka, którą przedstawia filozof napawa pesymizmem: „[...] człowiek całe życie dąży do szczęścia, osiąga zaś tylko jego namiastki i cierpienie. Oto prawdziwa i zarazem smutna dola człowieka" ${ }^{49}$.

\section{Poczucie nieszczęścia jako zjawisko wpisane w życie człowieka a możliwość osiagnięcia szczęścia}

Pesymistyczna wizja człowieka w świecie jest głównym tematem filozofii Arthura Schopenhauera (1788-1860). Cierpienie i nędza to kategorie w jakich przedstawia życie człowieka. Celem życia jest męka egzystencji. „Szczęścia ludzi nie należy mierzyć przyjemnością, ale brakiem cierpień [...]. Człowiek powinien stać się pokorny wobec goryczy swej egzystencji, stłumić w sobie wszelkie popędy, potrzeby (tj. wolę życia) i oddać się kontemplacji”" ${ }^{50}$. Od pesymizmu chroni ucieczka w nirwanę, która daje ukojenie.

Nuty pesymizmu przejawiają się w myśli egzystencjalnej J e a n a - Paula Sartre'a (1905-1980). Filozof zaznacza wprawdzie, że człowiek wybierając siebie wybiera zawsze dobro, które to dobro jest dobrem wszystkich i które należy afirmować. $Z$ drugiej strony mówi o beznadziejności, osamotnieniu i niepokoju. Niepokój dotyczy wyborów jakich człowiek dokonuje i odpowiedzialności za owe wybory. Osamotnienie jest związane z przyjmowaniem odpowiedzialności za swą wolność. „Osamotnienie narzuca samodzielny wybór własnego bytu. Osamotnieniu towarzyszy niepokój”' ${ }^{\prime 1}$.

Erich Fromm (1900-1980) przyznaje, że człowiek żyje w stanie braku równowagi. Boryka się ze sprzecznościami tkwiącymi w naturze: dychotomią między życiem a śmiercią, dychotomią miedzy realizacją wszystkich możliwości a brakiem ich realizacji. Owe

K. Kaszyński, Wybrane elementy flozofii cztowieka, dz. cyt., s. 81.

Tamże, s. 79.

E. Starzyńska-Kościuszko, Filozoficzne koncepcje cztowieka, Warszawa 1996, za: K. Kaszyński, Wybrane elementy filozofii cztowieka, dz. cyt., s. 90.

Za: S. Sarnowski, E. Frykowski, Problemy etyki, dz. cyt., s. 147. 
sprzeczności są nierozwiązywalne. Człowiek musi stawiać czoła poczuciu niespełnienia i brakowi harmonii. „Świadomość swej własnej sytuacji jest warunkiem osiągnięcia szczęścia, czyli możliwości realizowania własnych mocy: rozumu, miłości i pracy produktywnej”"52. Wolność „od”, związana z ucieczką od przyrody i instynktów, niesie cierpienie i samotność. Zjednoczenie ze światem jest możliwe dzięki niezależności i twórczemu rozumowi. Zadowolenie z życia może pojawić się gdy człowiek realizuje potrzeby we właściwy sposób. Fromm wśród różnych potrzeb wyróżnia: potrzebę ustosunkowania się, czyli tworzenia relacji z innymi (realizowaną poprzez miłość), transcendencji (zaspokajaną poprzez twórczość), zakorzenienia (realizowaną poprzez braterstwo), tożsamości (realizowaną dzięki indywidualizmowi), posiadania układu odniesienia i czci (zaspokajaną poprzez rozum). Dzięki realizacji dojrzałej osobowości, samowiedzy i twórczemu wykorzystaniu potencjalnych możliwości człowiek może żyć szczęśliwie ${ }^{53}$.

Rozpatrując zagadnienie szczęścia w kontekście psychologicznym, warto sięgnąc do „teorii cebulowej” Czapińskiego ${ }^{54}$. W modelu strukturalnym szczęścia autor zakłada, że najbardziej stabilną i odporną na doświadczenia sferą związaną ze szczęściem człowieka jest wewnętrzna wola życia. Teza ta jest zgodna $z$ arystotelesowską formułą, mówiącą o tym, że głównym celem ludzkiej działalności jest dążenie do szczęścia. Pośrednią warstwę w strukturze szczęścia stanowią przeżycia emocjonalne i ogólne zadowolenie z życia, zaś satysfakcje cząstkowe, będące oceną z poszczególnych dziedzin życia, wyznaczają warstwę powierzchniową - najbardziej zewnętrzną. Badania autora wykazały, że wola życia jako podstawowy wymiar szczęścia nie doznaje większych uszczerbków nawet w sytuacji naruszenia dobrostanu zewnętrznych warstw, tj. satysfakcji cząstkowych. Co więcej, ludzie nie potrzebują specjalnych powodów, by być szczęśliwymi. Powody te warunkują jednak poczucie nieszczęścia. Poczucie nieszczęścia należy do stanów przejściowych. Osoby dotknięte ciężkimi doświadczeniami życiowymi odzyskują jednak pozytywną postawę wobec życia. Ogólna ocena szczęścia nie jest

52 K. Kaszyński, Wybrane elementy filozofii cztowieka, dz. cyt., s. 113.

53 Tamże, s. 115.

54 Zob. J. Czapiński, Psychologia szczęścia, dz. cyt. 
zatem zdeterminowana czynnikami, które powszechnie traktuje się jako źródło przyjemności czy nieszczęścia. Założenia psychologii zbieżne są z filozoficznymi przesłankami dotyczącymi realizacji potrzeb dla poczucia szczęścia. Ludzie dążą do zaspokajania cząstkowych satysfakcji, zmotywowani są do realizacji potrzeb, w tym stojącej najwyżej w hierarchii potrzeb Abrahama Maslowa potrzeby samorealizacji. Upatrywanie szczęścia w sobie, wewnętrzne lokowanie szczęścia, sprzyja odporności i radzeniu sobie z przykrymi doświadczeniami. Dla dobrostanu psychicznego istotny jest stoicki dystans wobec wydarzeń zewnętrznych, czerpanie radości z wewnętrznych zasobów, optymistyczny, aczkolwiek niepozbawiony realizmu stosunek do życia i racjonalne wybory.

Według badań Czapińskiego hedonistyczne czerpanie z życia nie jest wyznacznikiem szczęścia. Na uwagę zasługuje fakt, że brak możliwości zaspokojenia potrzeb hedonistycznych istotnie wpływa na poczucie nieszczęścia, zaś samo posiadanie nie decyduje jeszcze o szczęściu. Okazuje się, że ze wzrostem statusu ekonomicznego (po przekroczeniu pewnej granicy zaspokojenia potrzeb komfortu) nie przybywa „więcej” szczęścia. Nie bez znaczenia dla dobrosta$\mathrm{nu}$ jednostki pozostają kontakty społeczne. Tezę tę wspierają dane wskazujące, że najbardziej zadowolone z życia są osoby pozostające w związkach, zaś istotną rolę dla radzenia sobie z przykrymi doświadczeniami pełni wsparcie ze strony innych. W omawianych badaniach wykazano również, że nie samo wyznawanie religii czy uznanie religii za źródło siły życiowej, ale praktykowanie wiary i przynależność do wspólnoty wyznaniowej są obiektywnym predyktorem szczęścia.

Kusząca wydaje się próba stworzenia uniwersalnego opisu osoby szczęśliwej (jak choćby: optymisty, żonatego, praktykującego religię itp.), jednakże proponowane psychologiczne charakterystyki w wielu wypadkach okazują się rozbieżne. Dzięki wykorzystaniu analiz statystycznych do badania zależności pomiędzy zewnętrznymi warunkami a poczuciem dobrostanu jednostek współczesne teorie stają się bardziej precyzyjne, niemniej jednak idee starożytnych myślicieli są wciąż aktualne w psychologii szczęścia. 


\section{Bibliografia}

Argyle M., The Psychology of Happiness, Methuen, London 1987.

Arystoteles, Etyka nikomachejska, przeł. D. Gromska, PWN, Warszawa 1956.

Bocheński J., Zarys historii filozofii, Wydawnictwo Philed, Kraków 1993.

Czapiński J., Psychologia szczęścia. Przegląd badań i zarys teorii cebulowei, "Akademos", Warszawa - Poznań 1992.

Epikur, List do Menoikeusa w: Diogenes Laertios, Żywoty i poglądy słynnych filozofów, przeł. I. Krońska, K. Leśniak, W. Olszewski, PWN, Warszawa 1988.

Hersch J., Wielcy myśliciele Zachodu. Dzieje filozoficznego zdziwienia, przeł. K. Wakar, Pruszyński i S-ka, Warszawa 2001.

Kaszyński K., Wybrane elementy filozofii człowieka, Wydawnictwo UZ, Zielona Góra 2002.

Kołakowski L., O co pytaja nas wielcy filozofowie, Znak, Kraków 2004.

Marek Aureliusz, Rozmyślania, przeł. M. Reiter, PWN, Warszawa 1958.

Mill J.S., Utylitaryzm. O wolności, przeł. A. Kurlandzka, Warszawa 1959.

Sarnowski S., E. Frykowski, Problemy etyki. Wybór tekstów, Agencja Marketingowa „Branta", Bydgoszcz 1993.

Seneka, Listy moralne do Lucyliusza, przeł. W. Kornatowski, PWN, Warszawa 1961.

Starzyńska-Kościuszko E., Filozoficzne koncepcje człowieka, Wyższa Szkoła Pedagogiczna TWP w Warszawie, Warszawa 1996.

Tatarkiewicz W., Historia filozofii, t. 1: Filozofia starożytna i średniowieczna, Wydawnictwo Naukowe PWN, Warszawa 1997.

Tatarkiewicz W., Historia filozofii, t. 2: Filozofia nowożytna do roku 1830, Wydawnictwo Naukowe PWN, Warszawa 1997.

Tatarkiewicz W., Historia filozofii, t. 3: Filozofia XIX wieku i współczesna, Wydawnictwo Naukowe PWN, Warszawa 1997.

Tatarkiewicz W., O szczęściu, wyd. 3, PWN, Warszawa 1962 [wyd. 7, PWN, Warszawa 1979].

Tomasz z Akwinu, Summa teologiczna (Contra Gentiles), cz. 1, t. 3, przeł. Z. Włodkowa, Nakładem „Wiadomości Katolickich”, Kraków 1933.

Veenhoven R., Conditions of Happiness, Reidel, Dordrecht 1984. 


\section{STRESZCZENIE SUMMARY}

Problematyka szczęścia jednostki jako temat mało popularny w psychologii i socjologii częściej staje się obecnie motywem rozważań i badań empirycznych w obrębie nauk humanistycznych. Sięgając do filozofii i historii myśli filozoficznej, tematyka szczęścia człowieka przewija się w wielu rozważaniach, chociaż należy zauważyć, że owe zapatrywania bywaja bardzo zróżnicowane, wielowq̨tkowe, rozbieżne, często skrajne. Sytuacja ta sprawia, że stworzenie kryteriów oraz zabieg uporzqdkowania teorii filozoficznych na temat szczęścia jest zadaniem bardzo trudnym. W artykule przedstawiono wybrane z historii myśli filozoficznej teorie na temat szczęścia. Odniesiono się do najstarszych myśli filozoficznych m.in. Sokratesa, Platona, Arystotelesa. Zwrócono uwage na motyw hedonistycznej przyjemności według Arystypa, Epikura, a także skrajnie odmienne stanowisko św. Augustyna, św. Tomasza z Akwinu czy Spinozy oparte na założeniu, że źródłem szczęścia jest sam Bóg. Przedstawiono również problematykę zabiegania o dobro własne według Hobbesa oraz znaczenie wartości utylitarnych. Możliwość zgłębiania wiedzy jako największe szczęście człowieka była owocem dynamicznego rozwoju nauki doby oświecenia. Wage rozumu podkreślał Kartezjusz, z kolei Locke zwracał uwage na znaczenie doświadczenia empirycznego. W odniesieniu do nurtu pesymistycznego w filozofii Schopenhavera i Sartre'a rozważano zagadnienia poczucia nieszczęścia wpisanego w ludzkq egzystencję. Aspekty myśli filozoficznej wzbogacono o zagadnienia nurtu psychologii szczęścia. Odwołano się do modelu strukturalnego Czapińskiego oraz wyników badań empirycznych nad czynnikami warunkującymi szczęście jednostki.
The issue of happiness as the subject hasn't been quite popular in psychology, sociology. Now it is becoming the motive of considerations and empirical studies. Human happiness theme is present in many philosophical considerations, although it should be noted that the understanding is diverse, multi-threaded, divergent and often extreme. This situation makes the establishment of criteria and set in order philosophical theories on happiness appears to be very difficult task. This article presents selected theories on happiness from the history of philosophy, with reference to issues of contemporary psychology of happiness. Reference was made to the oldest philosophical thoughts of Socrates, Plato, Aristotle. Drew attention to the hedonistic pleasures theme by Aristippus, Epicurus, as well as extremely different view of St. Augustine, St. Thomas Aquinas and Spinoza based on the assumption that the source of happiness is God. It also presents issues of focus on one's own well-being by Hobbes and the importance of utilitarian value. Opportunity to explore the knowledge as the greatest happiness of man was the result of the dynamic development of science. With regard to the pessimistic trend in the philosophy of Schopenhaver and Sartre issues of unhappiness considered as inherent in human existence. Aspects of philosophical issues were enriched with issues of psychology. Reference was made to the structural model of Czapiński and empirical researches on determinants of individual happiness.

\section{ADRES DO KORESPONDENCJI:}

\section{dr Agata Krasucka}

Studium Pedagogiczne Uniwersytetu Jagiellońskiego ul. Wiślna 3

\section{1-007 Kraków}

